\title{
Antimicrosporidial activity of (fluoro)quinolones in vitro and in vivo
}

\author{
Elizabeth S. Didier ${ }^{1}$, Lisa Bowers ${ }^{1}$, Mary E. Stovall ${ }^{1}$, Dorothy Kuebler ${ }^{2}$, Derek Mittleider ${ }^{3}$, Paul J. Brindley ${ }^{3}$ \\ and Peter J. Didier ${ }^{2}$
}

${ }^{1}$ Division of Microbiology and Immunology, ${ }^{2}$ Division of Comparative Pathology, Tulane National Primate Research Center, Covington, Louisiana 70433, USA;

${ }^{3}$ Department of Tropical Medicine, Tulane University Health Sciences Center, Tulane University, New Orleans, Louisiana 70112, USA

Key words: fluoroquinolone, microsporidia, opportunistic infection, emerging infection, Encephalitozoon intestinalis, Vittaforma corneae

\begin{abstract}
Microsporidia are a cause of emerging and opportunistic infections in humans and animals. Although two drugs are currently being used to treat microsporidiosis, concerns exist that albendazole is only selective for inhibiting some species of microsporidia that infect mammals, and fumagillin appears to have been found to be toxic. During a limited sequence survey of the Vittaforma corneae (syn. Nosema corneum Shadduck, Meccoli, Davis et Font, 1990) genome, a partial gene encoding for the ParC topoisomerase IV subunit was identified. The purpose of this set of studies was to determine if fluoroquinolones, which target topoisomerase IV, exert activity against Encephalitozoon intestinalis (syn. Septata intestinalis Cali, Kotler et Orenstein, 1993) and $V$. corneae in vitro, and whether these compounds could prolong survival of $V$. corneae-infected athymic mice. Fifteen fluoroquinolones were tested. Of these, norfloxacin and ofloxacin inhibited $E$. intestinalis replication by more than $70 \%$ compared with non-treated control cultures, while gatifloxacin, lomefloxacin, moxifloxacin, and nalidixic acid (sodium salt) inhibited both E. intestinalis and $V$. corneae by at least $60 \%$ at concentrations not toxic to the host cells. These drugs were tested in vivo also, where gatifloxacin, lomefloxacin, norfloxacin, and ofloxacin prolonged survival of $V$. corneae-infected athymic mice $(P<0.05)$, whereas moxifloxacin and nalidixic acid failed to prolong survival. Therefore, these results support continued studies for evaluating the efficacy of the fluoroquinolones for treating microsporidiosis and for characterizing the target(s) of these fluoroquinolones in the microsporidia.
\end{abstract}

Microsporidia are single-celled, obligately intracellular eukaryotic parasites that are recognized causes of emerging and opportunistic infections in persons with AIDS, organ transplant recipients, children, travellers, contact lens wearers, and the elderly (Bryan and Schwartz 1999, Didier 2005). Clinical symptoms associated with intestinal microsporidiosis typically include persistent diarrhoea, malabsorption, abdominal pain, and weight loss, and those associated with disseminated infections include conjunctivitis, sinusitis, myositis, pneumonia, peritonitis, hepatitis, or nephritis (Kotler and Orenstein 1998, 1999, Weber et al. 2000). Concerns for food- and water-borne transmission have resulted in the inclusion of microsporidia on the United States Environmental Protection Agency's microbial contaminant candidate list in response to the Safe Drinking Water Act (http://www.epa.gov/safewater/ccl/cclfs.html), and on the list of biodefence pathogens in Category B published by the National Institutes of Health and Centers for Disease Control and Prevention (http://www2.Niaid. Nih.Gov/Biodefense/bandc-priority.htm).

Current therapies for microsporidiosis are variably effective (Conteas et al. 2000). Albendazole, a benzimidazole that inhibits microtubule assembly, is effective against several microsporidia including the $E n$ cephalitozoon species, but is less effective against $E n$ - terocytozoon bieneusi (Blanshard et al. 1992). Fumagillin, a product of Aspergillus fumigatus that is well known for its effective treatment of nosematosis in honeybees (Katznelson and Jamieson 1952), also inhibits microsporidia in vitro (Shadduck 1980, Didier 1997) and is used topically to effectively treat ocular microsporidia infections (Friedberg and Ritterband 1999). Fumagillin appears to be effective against $E$. bieneusi infections in humans (Molina et al. 2002), but concerns exist about fumagillin's toxicity when used systemically in humans, which has generated interest in finding effective, but less toxic fumagillin analogues for treating microsporidiosis.

During studies to identify, clone, and express microsporidian methionine aminopeptidase 2, the putative drug target of fumagillin, a gene encoding topoisomerase IV was identified in the human microsporidian, Vittaforma corneae (Mittleider et al. 2002). Interestingly, topoisomerase IV has only been identified in prokaryotes. The genome of E. cuniculi includes genes for DNA topoisomerases I, II, and III, but no gene for DNA topoisomerase IV has been identified (Katinka et al. 2001). Of practical interest is that quinolones target

This paper was presented at the NATO Advanced Research Workshop "Emergent Pathogens in the 21st Century: First United Workshop on Microsporidia from Invertebrate and Vertebrate Hosts", held in České Budějovice, Czech Republic, July 12-15, 2004.

Address for correspondence: E.S. Didier, Division of Microbiology and Immunology, Tulane National Primate Research Center, 18703 Three Rivers Road, Covington, LA 70433, USA. Phone: ++1 985871 6249; Fax: ++1 985871 6248; E-mail: esdnda@tulane.edu 
the type II topoisomerases, DNA gyrase and topoisomerase IV (Hooper 2000, Andersson and MacGowan 2003, Hawkey 2003).

The purpose of this study was to test the in vitro and in vivo antimicrosporidial activities of a panel of fluoroquinolones. The in vitro screening assay utilized Encephalitozoon intestinalis and $V$. corneae. E. bieneusi is the most common microsporidian that infects humans but it cannot be grown in long-term culture and does not infect small laboratory animals. E. intestinalis was used in the in vitro screening assay because it is the secondmost common microsporidian infecting humans and can be grown in long-term tissue. The human microsporidian isolate of $V$. corneae was used in the in vitro and in vivo models because it was found to encode a gene for topoisomerase IV, which is a target of the fluoroquinolones, can be grown in tissue culture, is most closely related to E. bieneusi based on a comparison of ribosomal gene sequences, and causes lethal infections in athymic mice (Didier et al. 1994, Baker et al. 1995, Mittleider et al. 2002). In addition, $V$. corneae can serve as a surrogate for E. bieneusi in drug test models because both organisms replicate in the host cell cytoplasm and both organisms are relatively less sensitive to albendazole while Encephalitozoon species are relatively sensitive to albendazole (Didier 1997, Desportes-Livage 2000).

\section{MATERIALS AND METHODS}

Microsporidia. E. intestinalis and $V$. corneae were grown in RK-13 rabbit kidney cells (50506, 50505, and CCL-37, respectively, American Type Culture Collection, Manassas, VA) and supernatants containing the microsporidia were washed successively in sterile distilled water, Tris-buffered saline containing $0.3 \%$ Tween 20 (TBS-Tw), and TBS followed by density centrifugation in 50\% Percoll (Pharmacia, Picatoway, NJ) as previously described (Didier et al. 1996, Didier 1997)

Drugs. All drugs were purchased from Sigma Chemical (St. Louis, MO) with the exception of ciprofloxacin, gatifloxacin, levofloxacin, and moxifloxacin, which were provided through a contract with National Institute of Allergy and Infectious Diseases (N.I.A.I.D.) from Southern Research Institute (Frederick, MD). Stock solutions of drugs were prepared at $10 \mathrm{mM}$ in dimethylsulfoxide (DMSO) and further diluted in medium for testing in the in vitro screening assays or in saline for treating mice.

In vitro drug assay. $\mathrm{RK}-13$ cells were plated onto 96-well tissue culture plates at $5 \times 10^{4}$ cells per well in RPMI 1640 medium containing $2 \mathrm{mM}$ L-glutamine and $5 \%$ foetal bovine serum overnight at $37^{\circ} \mathrm{C}$ with $5 \% \mathrm{CO}_{2}$ to allow host cells to reach confluency. The next day, medium was replaced with $100 \mu 1$ fresh medium containing microsporidia $\left(1.5 \times 10^{5}\right.$ organisms resulting in a 3:1 ratio of parasites to cells) and 100 $\mu \mathrm{l}$ freshly-diluted drugs in medium to generate final concentrations of $100,10,1$, and $0.1 \mu \mathrm{M}$. Control cultures with microsporidia were treated with DMSO at the same dilution used to generate the $100 \mu \mathrm{M}$ drug dilution (i.e. 1:1,000). Fresh medium containing drugs or diluent was replaced in each well on days 3 and 7 . On day ten, $20 \mu 1$ of $10 \%$ (w/v) sodium dodecyl sulfate was added to each well with microsporidia to release organisms from the host cells and the number of microsporidia was counted on a haemacytometer. Each treatment was assayed in quadruplicate and the percent inhibition of microsporidia replication was calculated as equal to; 100 [(number of microsporidia in each treatment well / mean number of microsporidia in the non-treated wells) $\times 100]$.

Measurement of drug toxicity in vitro. Quadruplicate sets of RK-13 host cells not inoculated with microsporidia were treated with drug only as described above and host cell viability was measured using an MTT assay (3(4,5-dimethylthiazol-2-yl) 2,5 diphenyl tetrazolium bromide; Sigma, St. Louis, MO) as a measure of drug toxicity as described previously (Didier 1997). On day 10 of the assay, $50 \mu 1$ of MTT (5 $\mathrm{mg} / \mathrm{ml}$ stock) was added to each well and the cultures were incubated an additional $4 \mathrm{~h}$ at $37^{\circ} \mathrm{C}$. The supernatants were then removed and the formazan was dissolved by addition of $200 \mu 1$ acidified isopropanol. Absorbance values were measured using an ELISA spectrophotometer at a test wavelength of $570 \mathrm{~nm}$ and a reference wavelength of $630 \mathrm{~nm}$. The percent of host cell viability was calculated as equal to; [absorbance of drug-treated host cells / mean absorbance of non-treated host cells] $\times 100$. Drugs were considered toxic at concentrations that caused host cell viability to fall below $75 \%$ of diluent-treated control cultures.

Mice. Seven-week-old athymic CRL:CD-1nuBR male mice were purchased from Charles Rivers Laboratories (Wilmington, MA) and housed in groups of four in sterile filtertopped cages on HEPA-filtered shelf racks with sterile water and food provided ad libitum. Mice were allowed to acclimate for one week prior to initiation of the experiments. All protocols and procedures were approved by the Tulane National Primate Research Center Institutional Animal Care and Use Committee.

Microsporidia infection and treatment of mice. Mice were inoculated intraperitoneally with $1 \mathrm{ml}$ saline containing $1 \times 10^{7} \mathrm{~V}$. corneae. Drug or diluent injections were initiated $24 \mathrm{~h}$ later using doses and routes as described for each experiment. Mice were monitored for changes in activity, general appearance, body weight, and survival. If animals became moribund due to infection, or at the completion of the experiment, mice were euthanized by carbon dioxide overdose and necropsied. Gross abnormalities were recorded and histopathology was performed. Major organs including the brain, heart, liver, spleen, kidney, pancreas, gall bladder, stomach, lymph nodes, and adrenals were fixed by immersion in $10 \%$ formalin for histochemisty. In addition, the lung and the entire intestinal tract were perfused with fixative via the trachea and lumen prior to immersion. Tissues were embedded in paraffin for routine histologic processing and multiple sections were stained with H\&E and Gram stain. Without prior knowledge of treatment, one section of each tissue from each mouse received a lesion score (subjective score of $0-4$ ) and a parasite density score based on counting aggregates of Gram-positive microsporidia.

Statistical analyses. Means were compared by Student's $t$ test when comparing two groups, or by Analysis of Variance when comparing more than two groups. Approximate 50\% 
minimum inhibitory concentration $\left(\mathrm{MIC}_{50}\right)$ values were determined either experimentally or by linear regression and interpolation. The software programs of Graphpad Instat and Graphpad Prism software (San Diego, CA; website: www. graphpad.com) were used for these statistical analyses.

\section{RESULTS}

\section{In vitro screening}

Fifteen (fluoro)quinolones were assayed for their ability to inhibit replication of E. intestinalis and $V$. corneae in culture (Table 1). Norfloxacin and ofloxacin inhibited E. intestinalis replication by more than $70 \%$ compared with non-treated control cultures, while gatifloxacin, lomefloxacin, moxifloxacin, and nalidixic acid (sodium salt) inhibited both E. intestinalis and $V$. corneae by at least $60 \%$ at concentrations not toxic to the host cells. The lowest $\mathrm{MIC}_{50}$ values were observed for lomefloxacin, norfloxacin, and ofloxacin. In some cases, the $\mathrm{MIC}_{50}$ values needed to be interpolated to concentrations that were higher than could be tested in vitro due to toxicity to host cells.

\section{In vivo evaluation of test compounds}

Athymic mice inoculated i.p. with $1 \times 10^{7} \mathrm{~V}$. corneae succumbed to infection about two to three weeks later. Affected animals usually demonstrated weight loss, and ascites terminally. Livers were mottled with pinpoint grey foci and congested centrolobular zones. In infected animals that survived more than three weeks, hepatic lesions were inapparent, but the kidneys contained pinpoint grey-white foci in the polar cortex. Histologically during the acute disease typically 14-21 days after inoculation with $V$. corneae, lesions were primarily identified as peritonitis of the intestine and spleen, and necrosis and inflammation of the liver and pancreas (not shown). Acute lesions of the visceral peritoneum were characterized by deposition of fibrin, variable accumulations of polymorphonuclear leucocytes and mononuclear cells, and dense intracellular accumulations of Gram-positive microsporidial spores that could often be detected and enumerated at low microscopic power $(\times$ 4). In the liver, random foci of necrosis and/or neutrophilic infiltrations were accompanied by individual spores and clusters of microsporidia within hepatocytes. In the pancreas, individual acinar cells to entire acini were necrotic or distended by dense aggregates of microsporidia. In chronic infections where mice survived at least 21 days, scattered renal tubules were necrotic, infiltrated with neutrophils, and contained distended epithelial cells filled with microsporidia (not shown). The survival curves of athymic mice inoculated with $V$. corneae and treated with (fluoro)quinolones are shown in Fig. 1.

\section{Gatifloxacin}

Athymic mice infected with $V$. corneae survived an average of $15.8( \pm 0.4)$ days in this experiment. Gatifloxacin administered at doses of 25 and $50 \mathrm{mg} / \mathrm{kg}$ i.p. daily statistically significantly prolonged survival of the infected athymic mice to a mean of $20.1 \pm 1.8$ days $(P<$ $0.05)$ and a mean of $21.3 \pm 1.2$ days $(P<0.01)$, respectively, while $100 \mathrm{mg} / \mathrm{kg}$ i.p. daily resulted in a mean survival time of $16.6 \pm 0.7$ days which was not statistically significantly longer than the untreated infected mice. The mean numbers of parasite-associated lesions in one section of all tissues of all mice were compared between groups of treated and non-treated $V$. corneaeinfected athymic mice. An average of $126.0 \pm 35.9$ lesions were observed in the untreated infected mice. Infected mice treated with gatifloxacin at $25 \mathrm{mg} / \mathrm{kg}$ i.p. daily expressed a lower mean number of lesions at 89.7 \pm 34.4 per mouse, but this was not statistically significantly less than those observed in the untreated control mice. Statistically significantly fewer lesions were observed in the infected mice treated with gatifloxacin at $50 \mathrm{mg} / \mathrm{kg}$ i.p. daily $(53.9 \pm 40.9$ lesions; $P<0.01)$ and $100 \mathrm{mg} / \mathrm{kg}$ i.p. daily $(25.6 \pm 16.5$ lesions; $P<0.001)$ compared with those observed in the untreated control mice. The observation that mice treated with the higher dose of gatifloxacin at $100 \mathrm{mg} / \mathrm{kg}$ i.p. daily failed to survive longer, even though parasite-associated lesions were significantly reduced, suggested that this drug was toxic at this dose. This was further supported by findings that five of the eight uninfected athymic mice in the toxicity control group treated with gatifloxacin 100 $\mathrm{mg} / \mathrm{kg}$ i.p. daily failed to survive the four-week duration of the experiment and had developed suppurative and chronic peritonitis as observed at necropsy and by histopathology.

\section{Lomefloxacin}

In this experiment, the athymic mice inoculated with $V$. corneae survived an average of $21.4 \pm 1.6$ days. The mean survival time of the infected athymic mice treated with lomefloxacin at $50 \mathrm{mg} / \mathrm{kg}$ i.p. daily was $22.8 \pm 1.0$ which was not significantly longer than the controls. The mean survival times were significantly longer for the infected athymic mice treated with lomefloxacin at $100 \mathrm{mg} / \mathrm{kg}$ i.p. daily $(25.7 \pm 5.1$ days; $P<0.05)$ and 200 $\mathrm{mg} / \mathrm{kg}$ i.p. daily $(25.8 \pm 3.6$ days; $P<0.05)$. The mean numbers of parasite-associated lesions observed histologically were lower in the treated versus untreated infected athymic mice, but these values were not statistically significant. Toxicity control athymic mice treated with lomefloxacin at $200 \mathrm{mg} / \mathrm{kg}$ i.p. daily survived the length of the experiment, but mild focal peritonitis was noted in six of the eight mice.

\section{Moxifloxacin}

The mean survival time of the untreated $V$. corneaeinfected athymic mice in this experiment was $22.8 \pm 2.3$ days. The infected athymic mice treated with moxifloxacin at 25, 50, and $100 \mathrm{mg} / \mathrm{kg}$ i.p. daily survived an average of $25.6 \pm 2.1,25.3 \pm 2.6$, and $20.9 \pm 7.6$ days, respectively, and none of these survival times were significantly longer than the average survival time of the 
Table 1. Screening of (fluoro)quinolones for antimicrosporidial activity in vitro.

\begin{tabular}{|c|c|c|c|c|c|}
\hline \multirow[t]{2}{*}{ Compound } & \multirow{2}{*}{$\begin{array}{l}\text { Highest non-toxic } \\
\text { dose tested }^{\text {a }}\end{array}$} & \multicolumn{2}{|c|}{ Percent inhibition $\left(\right.$ mean \pm SD) ${ }^{b}$} & \multicolumn{2}{|c|}{ Approximate $\mathrm{MIC}_{50}(\mu \mathrm{M})^{\mathrm{c}}$} \\
\hline & & $\begin{array}{c}\text { Encephalitozoon } \\
\text { intestinalis }\end{array}$ & $\begin{array}{l}\text { Vittaforma } \\
\text { corneae }\end{array}$ & $\begin{array}{c}\text { Encephalitozoon } \\
\text { intestinalis }\end{array}$ & $\begin{array}{l}\text { Vittaforma } \\
\text { corneae }\end{array}$ \\
\hline Cinoxacin & $10 \mu \mathrm{M}$ & $1.7 \pm 6.6$ & $12.1 \pm 9.2$ & 55 & 49 \\
\hline Ciprofloxacin & $10 \mu \mathrm{M}$ & $2.9 \pm 3.6$ & $4.2 \pm 3.9$ & 84 & 66 \\
\hline Enoxacin & $10 \mu \mathrm{M}$ & $28.6 \pm 3.6$ & $10.4 \pm 12.8$ & 69 & 60 \\
\hline Flumequine & $0.1 \mu \mathrm{M}$ & $0.5 \pm 5.6$ & $12.8 \pm 2.82$ & 359 & 132 \\
\hline Gatifloxacin & $100 \mu \mathrm{M}$ & $60.4 \pm 2.3$ & $66.1 \pm 2.6$ & 85 & 73 \\
\hline 8-Hydroxyquinolone & $0.1 \mu \mathrm{M}$ & $-0.5 \pm 4.9$ & $7.6 \pm 3.6$ & 53 & 52 \\
\hline Levofloxacin & $<0.1 \mu \mathrm{M}$ & toxic & toxic & n.d. ${ }^{d}$ & n.d. \\
\hline Lomefloxacin & $100 \mu \mathrm{M}$ & $98.4 \pm 0.1$ & $98.3 \pm 0.2$ & 3 & 3 \\
\hline Moxifloxacin & $100 \mu \mathrm{M}$ & $66.5 \pm 3.7$ & $64.3 \pm 4.1$ & 76 & 77 \\
\hline Nalidixic acid (free acid) & $10 \mu \mathrm{M}$ & $20.6 \pm 4.1$ & $14.3 \pm 9.2$ & 50 & 66 \\
\hline Nalidixic acid (sodium salt) & $100 \mu \mathrm{M}$ & $98.9 \pm 0.1$ & $73.6 \pm 10.0$ & 23 & 66 \\
\hline Norfloxacin & $10 \mu \mathrm{M}$ & $85.7 \pm 1.8$ & $43.6 \pm 2.8$ & 1 & 24 \\
\hline Novobiocin & $100 \mu \mathrm{M}$ & $-7.3 \pm 3.8$ & $8.7 \pm 5.0$ & $>100$ & $>100$ \\
\hline Ofloxacin & $10 \mu \mathrm{M}$ & $78.2 \pm 2.3$ & $23.3 \pm 5.3$ & 2 & 54 \\
\hline Pipemidic acid & $10 \mu \mathrm{M}$ & $0.9 \pm 7.0$ & $2.6 \pm 6.8$ & $>100$ & $>100$ \\
\hline
\end{tabular}

${ }^{a}$ Test compounds were considered toxic if host cell viability fell below $75 \%$ of control host cells that were incubated in compound-free medium.

${ }^{\mathrm{b}}$ The inhibition of microsporidian growth was reported for the highest concentration of drug treatment that was not toxic to the host cells. At higher drug concentrations, it was not possible to determine if microsporidia growth inhibition was due to direct effects of drug on the microsporidia or indirect effect from loss of host cells for supporting growth of microsporidia.

${ }^{c} \mathrm{MIC}_{50}$ values were measured by linear regression of experimental values and interpolation using Graphpad Prism 4. In some cases, the estimated values exceeded the highest non-toxic concentrations tested in this screening assay.

${ }^{\mathrm{d}}$ n.d.; not determined due to toxicity at all doses tested in this screening.

infected untreated control mice. In addition, no statistically significant reduction in the mean numbers of parasite-associated lesions were observed for any of the treatment groups. The uninfected toxicity control mice treated with moxifloxacin at $100 \mathrm{mg} / \mathrm{kg}$ i.p. daily survived the term of the experiment and chronic peritonitis was observed in three of the eight mice.

\section{Nalidixic acid (sodium salt)}

The untreated infected athymic control mice survived an average of $23.7 \pm 0.8$ days in this experiment. Infected athymic mice treated with nalidixic acid at 25 , 50 , and $100 \mathrm{mg} / \mathrm{kg}$ i.p. daily survived for $23.0 \pm 0,25.3$ \pm 4.1 , and $25.9 \pm 4.5$ days, respectively, which were not statistically significantly longer than the mean survival time of the untreated infected athymic mice. The mean numbers of parasite-associated lesions, likewise were not significantly lower than that of the untreated infected control mice. Toxicity control athymic mice treated with nalidixic acid at $100 \mathrm{mg} / \mathrm{kg}$ i.p. daily survived the length of the experiment and no lesions associated with drug toxicity were observed.

\section{Norfloxacin}

In this experiment, the mean survival time of the untreated athymic mice inoculated with $V$. corneae was $19.0 \pm 1.9$ days. Norfloxacin statistically significantly prolonged survival times of mice treated at $50 \mathrm{mg} / \mathrm{kg}$ i.p. daily $(25.9 \pm 1.8$ days; $P<0.001), 100 \mathrm{mg} / \mathrm{kg}$ i.p. daily $(26.8 \pm 0.7$ days; $P<0.001)$, and $200 \mathrm{mg} / \mathrm{kg}$ i.p. daily $(25.4 \pm 2.6$ days; $P<0.01)$. The mean numbers of parasite-associated lesions also were significantly reduced in mice treated with norfloxacin at $50 \mathrm{mg} / \mathrm{kg}$ i.p. daily $(30.1 \pm 26.6$ lesions; $P<0.05), 100 \mathrm{mg} / \mathrm{kg}$ i.p. daily $(17.9 \pm 25.6$ lesions; $P<0.01)$, and $200 \mathrm{mg} / \mathrm{kg}$ i.p. daily $(16.1 \pm 17.1 ; P<0.01)$ compared with untreated infected mice that had a mean of $73.9 \pm 43.2$ lesions per mouse. Although the toxicity control athymic mice treated with norfloxacin at $200 \mathrm{mg} / \mathrm{kg}$ i.p. daily survived the length of this experiment, suppurative peritonitis was observed in all of these mice.

\section{Ofloxacin}

The mean survival time of the untreated $V$. corneaeinfected athymic mice in this experiment was $23.7 \pm 0.8$ days and all treatment groups survived statistically significantly longer. Infected athymic mice treated with ofloxacin at 25,50 , and $100 \mathrm{mg} / \mathrm{kg}$ i.p. daily survived an average of $28.4 \pm 2.2$ days $(P<0.001), 28.3 \pm 2.1$ days $(P<0.001)$, and $28.3 \pm 2.5$ days $(P<0.001)$, respectively. The mean number of parasite-associated lesions, however, were not significantly reduced in tissues of the treated mice. The toxicity control athymic mice treated with ofloxacin at $100 \mathrm{mg} / \mathrm{kg}$ i.p. daily survived the length of the experiment and no lesions associated with drug toxicity were observed in any of these mice. 
Gatifloxacin

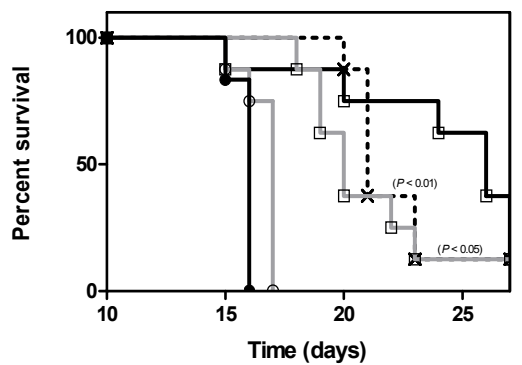

Moxifloxacin

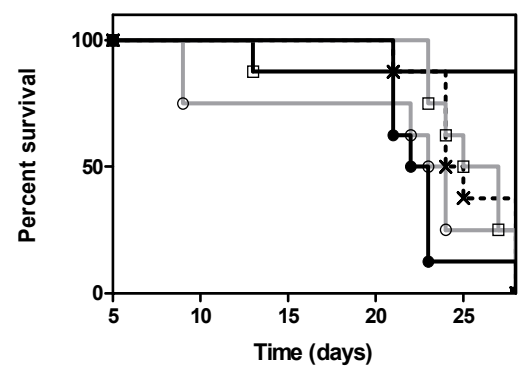

Norfloxacin

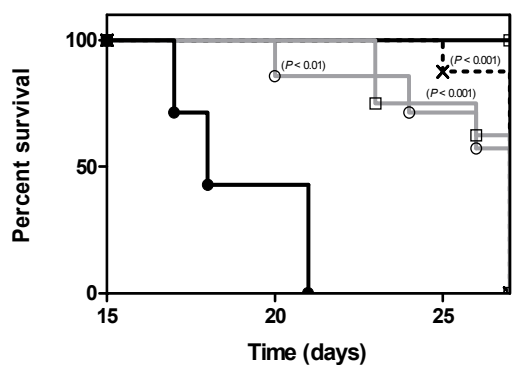

$\rightarrow-V$.corneae only

$\square-V_{c}+$ Gatifloxacin $(25 \mathrm{mg} / \mathrm{kg})$

* - Vc + Gatifloxacin $(50 \mathrm{mg} / \mathrm{kg})$

- $V c+$ Gatifloxacin $(100 \mathrm{mg} / \mathrm{kg})$

$\rightarrow$ Gatifloxacin $(100 \mathrm{mg} / \mathrm{kg})$ only

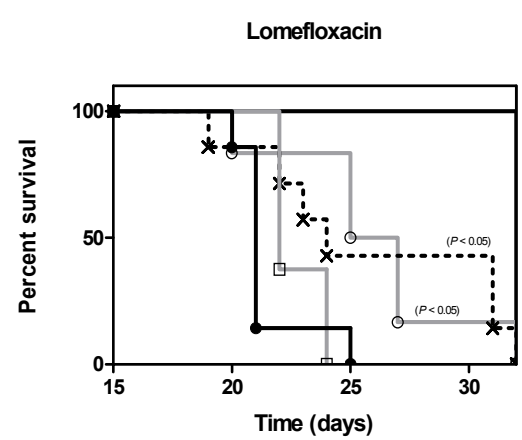

Nalidixic acid (sodium salt)

\section{- V.corneae only}

$\square-\mathrm{Vc}+$ Moxifloxacin $(25 \mathrm{mg} / \mathrm{kg})$

* - Vc + Moxifloxacin $(50 \mathrm{mg} / \mathrm{kg})$

$0-V_{c}+$ Moxifloxacin $(100 \mathrm{mg} / \mathrm{kg})$

- Moxifloxacin (100 mg/kg) only
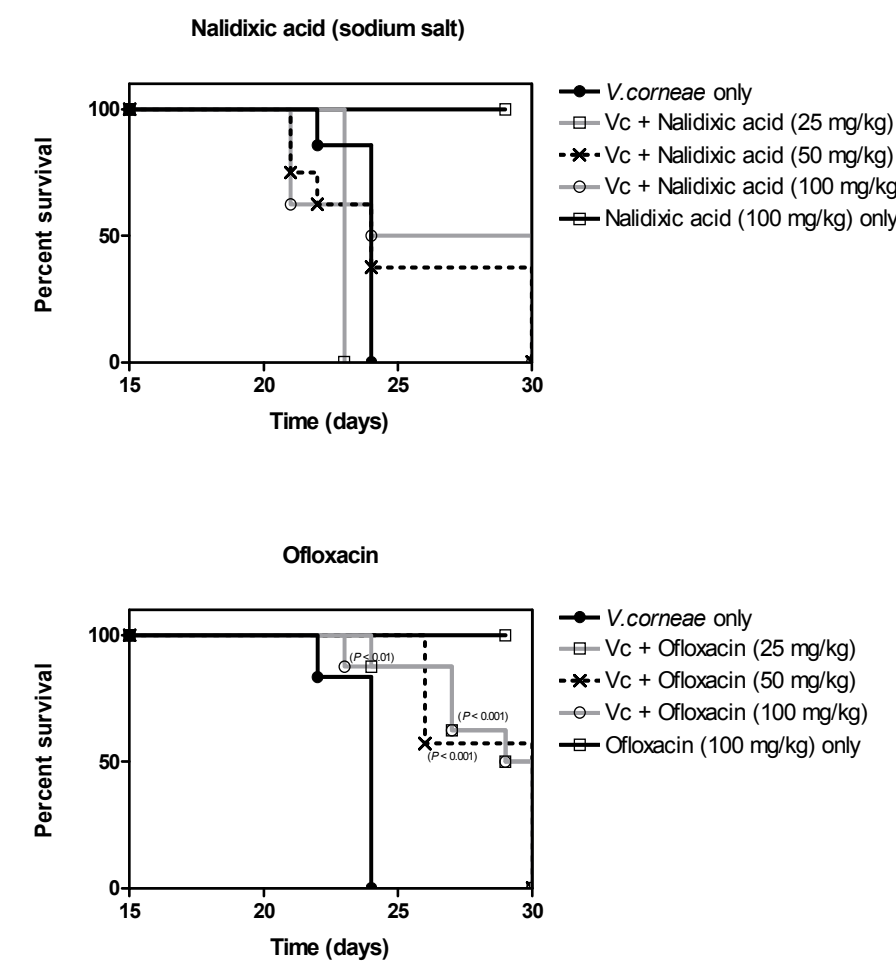

Fig. 1. Survival curves of Vittaforma corneae-infected mice treated with fluoroquinolones. 


\section{DISCUSSION}

Fluoroquinolones are antimicrobial compounds that are structurally related to the antimalarial quinolone drugs (Andersson and MacGowan 2003, Emmerson and Jones 2003). Nalidixic acid was the first quinolone developed and applied for treating urinary tract infections due to Gram-negative bacteria. Modification of nalidixic acid led to the development of new quinolones, including the fluoroquinolones, which also are active against systemic infections due to specific Grampositive, Gram-negative, and atypical bacteria. The fluoroquinolones are currently known to target two bacterial enzymes, DNA gyrase and topoisomerase IV. DNA gyrase is a tetramer composed to two A and two B subunits encoded by genes designated gyrA and $g y r B$, respectively, that introduces negative superhelical twists in DNA for initiation of DNA replication (Drlica and Zhao 1997, Ball 2000, Hooper 2000, Hawkey 2003). In addition, DNA gyrase removes superhelical twists that are generated ahead of the replication fork or during gene transcription. Topoisomerase IV is composed of two $\mathrm{C}$ and two $\mathrm{E}$ subunits encoded by genes designated $\operatorname{par} C$ and parE, respectively. This enzyme causes decatenation of intertwined daughter chromosomes to allow for segregation of daughter cells and also relaxes negative DNA supercoils (Ball 2000, Hooper 2000, Hawkey 2003). The fluoroquinolones inhibit DNA gyrase and topoisomerase IV by preventing religation of the broken DNA strands through formation of quinolone-enzyme-DNA complexes. Fluoroquinolones vary in their antibacterial activity by preferentially targeting DNA gyrase, DNA topoisomerase IV, or both. Bacterial resistance to fluoroquinolone activity may also occur through alteration in quinolone targets, decreased uptake of the drugs, expression of efflux pump systems, and mobile elements which may confer resistance (Ince and Hooper 2003, Ruiz 2003).

Topoisomerases that cleave one strand of DNA are classified as type I enzymes and those that cleave both strands of DNA are classified as type II topoisomerases and subtypes are defined by their linkage to the 5' or 3' phosphate or other structural considerations (Champoux 2001). Bacteria (e.g. Escherichia coli) typically contain two type IA topoisomerases (topoisomerase I and topoisomerase III) and two type IIA topoisomerases (DNA gyrase and topoisomerase IV). Some eubacteria may lack one of these enzymes due to redundant activities of their existing topoisomerases. Yeasts (e.g. Saccharomyces cerevisiae and Schizosaccharomyces pombe) contain topoisomerase I (belonging to topoisomerase type IB), topoisomerase II (of the topoisomerase type IIA), and topoisomerase III (of topoisomerase type IA). Higher eukaryotes typically contain topoisomerase I, two type IIA topoisomerases (topoisomerases II $\alpha$ and IIß), and two topoisomerase III enzymes (topoisom- erases III $\alpha$ and III $\beta$ ) which belong to the topoisomerase type I family.

Microsporidia are eukaryotic organisms that were recently reclassified with the fungi due to numerous related characteristics (Cavalier-Smith 1998, Weiss et al. 1999, Keeling and Fast 2002, Vossbrinck et al. 2004). The microsporidia, however, also share some characteristics with prokaryotes including the smaller size and organisation of their ribosomes and relatively few introns in the genome (Vossbrinck et al. 1987, Weiss et al. 1999). During a limited sequence survey of the Vittaforma corneae genome, a partial gene sequence encoding for 193 deduced amino acid residues was found to share a high level of identity to the DNA topoisomerase IV C subunit (type II; GenBank acc. nos. AZ694766, AZ694767, BH614712) of Borrelia burgdorferi (Mittleider et al. 2002). Furthermore, this $V$. corneae sequence was found to be more similar to the prokaryotic type II topoisomerase than to the Encephalitozoon $\mathrm{cu}$ niculi or eukaryotic type II topoisomerase. Since the entire $V$. corneae genome has yet to be determined, it is unknown if $V$. corneae contains other topoisomerases. The only microsporidian whose genome has been completely sequenced is E. cuniculi, and this species was found to encode genes for topoisomerase I (type I; GenBank acc. no. ECU06 1520), topoisomerase II (type II; GenBank acc. no. ECU04 0350), and topoisomerase III (type I; GenBank acc. no. ECU04 1070) (Katinka et al. 2001). A gene encoding for topoisomerase II (sequence 14VII-9F) was described for Spraguea lophii, but no gene encoding for topoisomerase IV was reported (Hinkle et al. 1997).

Since $V$. corneae was found to carry at least a partial gene encoding for the ParC subunit of topoisomerase IV, these studies were performed to determine if fluoroquinolones could exert antimicrosporidial activity. Of the 15 (fluoro)quinolones tested in vitro, two compounds, norfloxacin and ofloxacin, inhibited Encephalitozoon intestinalis by more than $70 \%$. Four of these compounds, gatifloxacin, lomefloxacin, moxifloxacin, and nalidixic acid (sodium salt), inhibited both $E$. intestinalis and $V$. corneae by more than $60 \%$. These drugs were then tested in vivo, and gatifloxacin, lomefloxacin, norfloxacin, and ofloxacin, were found to statistically significantly prolong survival of $V$. corneae-infected athymic mice. Moxifloxacin and nalidixic acid failed to prolong survival. Ciprofloxacin was tested in vivo, as well, because it is the most widely prescribed fluoroquinolone, but it did not significantly prolong survival of the $V$. corneae-infected athymic mice at 25,50 , or $100 \mathrm{mg} / \mathrm{kg}$ i.p. daily (data not shown). The wide variation in activity against $V$. corneae and E. intestinalis that was noted among the different fluoroquinolones thus may be due to the possibility that these two species of microsporidia may contain different types of topoisomerases and that the fluoroquinolones have different 
mechanisms of action (Ball 2000, Hooper 2000, Hawkey 2003).

(Fluoro)quinolones are primarily used for treating specific bacterial infections and are only rarely applied to studies on parasitic protozoan infections (Nenortas et al. 1999, Ball 2000, Hooper 2000, 2001). These compounds are structurally related to antimalarial quinolones, and a few fluoroquinolones, including trovafloxacin, ciprofloxacin, enoxacin, ofloxacin, and norfloxacin were shown to inhibit Plasmodium falciparum and Trypanosoma brucei brucei growth in vitro (Divo et al. 1988, Tripathi et al. 1993, Nenortas et al. 1998, 1999, Hamzah et al. 2000). Norfloxacin also was reported to be effective for treating $P$. falciparum and Plasmodium vivax infections in India (Sarma 1989, Tripathi et al. 1993), but ciprofloxacin was ineffective against multidrug resistant $P$. falciparum infections in Thailand (Watt et al. 1991). Trovafloxacin, grepafloxacin, gatifloxacin, and moxifloxacin were among the most effective of 24 (fluoro)quinolones tested for their ability to inhibit Toxoplasma gondii replication in vitro (Gozalbes et al. 2000). Ciprofloxacin also was found to inhibit in vitro replication of Giardia lamblia (Sousa and Poiares-da-Silva 2001) and T. gondii (Fichera and Roos 1997), particularly during the second infectious cell cycle in the latter case which was associated with reduction in plastid replication. Ciprofloxacin was ineffective in vivo, however, for treating mice with experimental T. gondii infection (Khan et al. 1996). P. falciparum mitochondrial DNA topoisomerase II and DNA gyrase activities were not inhibited in vitro in the presence of ofloxacin, ciprofloxacin, and norfloxacin suggesting to the investigators that the in vitro activity of these fluoroquinolones for inhibiting P. falciparum was instead probably due to targeting of the plastid DNA topoisomerase II, as was reported for T. gondii (Chavalitshewinkoon-Petmir et al. 2001).

The only published application of fluoroquinolones for treating microsporidiosis was by Chan et al. (2003) in which norfloxacin was used topically for microsporidial keratoconjunctivitis in combination with systemic albendazole therapy. The results of the studies presented in this report suggest that although none of the fluoroquinolones cleared the $V$. corneae infection from the athymic mice, several fluoroquinolones did statistically significantly prolong survival and might be more efficacious when used in combination with other drugs. For example, fumagillin, though active against microsporidia, was found to be somewhat toxic in humans (Molina et al. 2002), but perhaps when administered at lower non-toxic doses in combination with fluoroquinolones, may show greater efficacy. In practice, the combination of enrofloxacin in combination with metronidazole was effective for treating canine leishmaniasis (Bianciardi et al. 2004) and trovafloxacin, in combination with clarithromycin, pyrimethamine, or sulfa-diazine, was more effective than each compound alone for treating acute murine toxoplasmosis (Khan et al. 1997). These results would therefore support continued studies to determine if fluoroquinolones can be applied for successfully treating microsporidiosis and to further characterize and identify the topoisomerase drug targets in the microsporidia.

Acknowledgements. This work was funded by a contract from the National Institutes of Health (AI-NO1-75327) and we gratefully acknowledge the support and advice of our project officer, Dr. Susan W. Brobst.

\section{REFERENCES}

ANDERSSON M.I., MacGOWAN A.P. 2003: Development of the quinolones. J. Antimicrob. Chemother. 51 (Suppl. 1): $1-11$.

BAKER M.D., VOSSBRINCK C.R., DIDIER E.S., MADDOX J.V., SHADDUCK J.A. 1995: Small subunit ribosomal DNA phylogeny of various microsporidia with emphasis on AIDS related forms. J. Eukaryot. Microbiol. 42: 564-570.

BALL P. 2000: Quinolone generations: natural history or natural selection? J. Antimicrob. Chemother. 46 (Suppl. T1): 17-24.

BIANCIARDI P., FASANELL A., FOGLIA A., MANZILLO V., TROTTA T., PAGANO A., SORINO S., GRADONI L., OLIVA G. 2004: The efficacy of enrofloxacin, alone or combined with metronidazole, in the therapy of canine leishmaniasis. Parasitol. Res. 93: 486-492.

BLANSHARD C., ELLIS D.S., TOVEY D.G., DOWELL S., GAZZARD B.G. 1992: Treatment of intestinal microsporidiosis with albendazole in patients with AIDS. AIDS 6: 311-313.
BRYAN R.T., SCHWARTZ D.A. 1999: Epidemiology of microsporidiosis. In: M. Wittner and L.M. Weiss (Eds.), The Microsporidia and Microsporidiosis. ASM Press, Washington, D.C., pp. 502-516.

CALI A., KOTLER D.P., ORENSTEIN J.M. 1993: Septata intestinalis $\mathrm{n}$. g., n. sp., an intestinal microsporidian associated with chronic diarrhea and dissemination in AIDS patients. J. Eukaryot. Microbiol. 40: 101-112.

CAVALIER-SMITH T. 1998: A revised six-kingdom system of life. Biol. Rev. Camb. Philos. Soc. 73: 203-266.

CHAMPOUX J.J. 2001: DNA topoisomerases: structure, function, and mechanism. Ann. Rev. Biochem. 70: 369413.

CHAN C.M., THENG J.T., LI L., TAN D.T. 2003: Microsporidial keratoconjunctivitis in healthy individuals: a case series. Ophthalmology 110: 1420-1425.

CHAVALITSHEWINKOON-PETMITR P., WORASING R., WILAIRAT P. 2001: Partial purification of mitochondrial DNA topoisomerase II from Plasmodium falciparum and its sensitivity to inhibitors. S.E. Asian J. Trop. Med. Public Health 32: 733-738. 
CONTEAS C.N., BERLIN O.G., ASH L.R., PRUTHI J.S. 2000: Therapy for human gastrointestinal microsporidiosis. Am. J. Trop. Med. Hyg. 63: 121-127.

DESPORTES-LIVAGE I. 2000: Biology of microsporidia. Contrib. Microbiol. 6: 140-165.

DIDIER E.S. 1997: Effects of albendazole, fumagillin, and TNP-470 on microsporidia replication in vitro. Antimicrob. Agents Chemother. 41: 1541-1546.

DIDIER E.S. 2005: Microsporidiosis: an emerging and opportunistic infection in humans and animals. Acta Trop. 94: 61-76.

DIDIER E.S., ROGERS L.B., ORENSTEIN J.M., BAKER M.D., VOSSBRINCK C.R., VAN GOOL T., HARTSKEERL R., SOAVE R., BEAUDET L.M. 1996: Characterization of Encephalitozoon (Septata) intestinalis isolates cultured from nasal mucosa and bronchoalveolar lavage fluids of two AIDS patients. J. Eukaryot. Microbiol. 43: 34-43.

DIDIER E.S., VARNER P.W., DIDIER P.J., ALDRAS A.M., MILLICHAMP N.J., MURPHEY-CORB M., BOHM R.P., SHADDUCK J.A. 1994: Experimental microsporidiosis in immunocompetent and immunodeficient mice and monkeys. Folia Parasitol. 41: 1-11.

DIVO A.A., SARTORELLI A.C., PATTON C.L., BIA F.J. 1988: Activity of fluoroquinolone antibiotics against Plasmodium falciparum in vitro. Antimicrob. Agents Chemother. 32: 1182-1186.

DRLICA K., ZHAO X. 1997: DNA gyrase, topoisomerase IV, and the 4-quinolones. Microbiol. Mol. Biol. Rev. 61: 377-392.

EMMERSON A.M., JONES A.M. 2003: The quinolones: decades of development and use. J. Antimicrob. Chemother. 51 (Suppl. 1): 13-20.

FICHERA M.E., ROOS D.S. 1997: A plastid organelle as a drug target in apicomplexan parasites. Nature 390: 407409.

FRIEDBERG D.N., RITTERBAND D.C. 1999: Ocular microsporidiosis. In: M. Wittner and L.M. Weiss (Eds.), The Microsporidia and Microsporidiosis. ASM Press, Washington, D.C., pp. 293-314.

GOZALBES R., BRUN-PASCAUD M., GARCIA-DOMENECH R., GALVEZ J., GIRARD P.M., DOUCET J.P., DEROUIN F. 2000: Anti-toxoplasma activities of 24 quinolones and fluoroquinolones in vitro: prediction of activity by molecular topology and virtual computational techniques. Antimicrob. Agents Chemother. 44: 2771-2776.

HAMZAH J., SKINNER-ADAMS T., DAVIS T.M. 2000: In vitro antimalarial activity of trovafloxacin, a fourth-generation fluoroquinolone. Acta Trop. 74: 39-42.

HAWKEY P.M. 2003: Mechanisms of quinolone action and microbial response. J. Antimicrob. Chemother. 51 (Suppl. 1): 29-35.

HINKLE G., MORRISON H.G., SOGIN M.L. 1997: Genes coding for reverse transcriptase, DNA-directed RNA polymerase, and chitin synthase from the microsporidian Spraguea lophii. Biol. Bull. 193: 250-251. (http://jbpc.mbl. edu/Spraguea-html/)

HOOPER D.C. 2000: Mechanisms of action and resistance of older and newer fluoroquinolones. Clin. Infect. Dis. 31 (Suppl. 2): S24-S28.
HOOPER D.C. 2001: Mechanisms of action of antimicrobials: focus on fluoroquinolones. Clin. Infect. Dis. 32 (Suppl. 1): 9-15.

INCE D., HOOPER D.C. 2003: Quinolone resistance due to reduced target enzyme expression. J. Bacteriol. 185: 6883-6892.

KATINKA M.D., DUPRAT S., CORNILLOT E., MÉTÉNIER G., THOARAT F., PRENSIER G., BARE V., PEYRETAILLADE E., BROTTIER P., WINCKER P., DELBAC F., El ALAOUI H., PEYRET P., SAURIN W., GOUY M., WEISSENBACH J., VIVARÈS C.P. 2001: Genome sequence and gene compaction of the eukaryote parasite Encephalitozoon cuniculi. Nature 414: 450-453.

KATZNELSON H., JAMIESON C.A. 1952: Control of nosema disease of honeybees with fumagillin. Science 115: 70-71.

KEELING P.J., FAST N.M. 2002: Microsporidia: biology and evolution of highly reduced intracellular parasites. Ann. Rev. Microbiol. 56: 93-116.

KHAN A.A., SLIFER T., ARAUJO F.G., POLZER R.J., REMINGTON J.S. 1997: Activity of trovafloxacin in combination with other drugs for treatment of acute murine toxoplasmosis. Antimicrob. Agents Chemother. 41: 893-897.

KHAN A.A., SLIFER T., ARAUJO F.G., REMINGTON J.S. 1996: Trovafloxacin is active against Toxoplasma gondii. Antimicrob. Agents Chemother. 40: 1855-1859.

KOTLER D.P., ORENSTEIN J.M. 1998: Clinical syndromes associated with microsporidiosis. Adv. Parasitol. 40: 321349.

KOTLER D.P., ORENSTEIN J.M. 1999: Clinical syndromes associated with microsporidiosis. In: M. Wittner and L.M. Weiss (Eds.), The Microsporidia and Microsporidiosis. ASM Press, Washington, D.C., pp. 258-292.

MITTLEIDER D., GREEN L.C., MANN V.H., MICHAEL S.F., DIDIER E.S., BRINDLEY P.J. 2002: Survey of genome sequences from the opportunistic microsporidian pathogen, Vittaforma corneae. J. Eukaryot. Microbiol. 49: 393-401.

MOLINA J.M., TOURNEUR M., SARFATI C., CHEVRET S., DE GOUVELLO A., GOBERT J.G., BALKAN S., DEROUIN F. and Agence Nationale de Recherches sur le SIDA 090 Study Group. 2002: Fumagillin treatment of intestinal microsporidiosis. N. Engl. J. Med. 346: 19631969.

NENORTAS E.C., BODLEY A.L., SHAPIRO T.A. 1998: DNA topoisomerases: a new twist for antiparasitic chemotherapy? Biochim. Biophys. Acta 1400: 349-354.

NENORTAS E., BURRI C., SHAPIRO T.A. 1999: Antitrypanosomal activity of fluoroquinolones. Antimicrob. Agents Chemother. 43: 2066-2068.

NENORTAS E., KULIKOWICZ T., BURRI C., SHAPIRO T.A. 2003: Antitrypanosomal activities of fluoroquinolones with pyrrolidinyl substitutions. Antimicrob. Agents Chemother. 47: 3015-3017.

RUIZ J. 2003: Mechanisms of resistance to quinolones: target alterations, decreased accumulation and DNA gyrase protection. J. Antimicrob. Chemother. 51: 1109-1117.

SARMA P.S. 1989: Norfloxacin: a new drug in the treatment of falciparum malaria. Ann. Intern. Med. 111: 336-337. 
SHADDUCK J.A. 1980: Effect of fumagillin on in vitro multiplication of Encephalitozoon cuniculi. J. Protozool. 27: 202-208.

SHADDUCK J.A., MECCOLI R.A., DAVIS R., FONT R.L. 1990: Isolation of a microsporidian from a human patient. J. Infect. Dis. 162: 773-776.

SOUSA M.C., POIARES-da-SILVA J. 2001: The cytotoxic effects of ciprofloxacin in Giardia lamblia trophozoites. Toxicol. In Vitro 15: 297-301.

TRIPATHI K.D., SHARMA A.K., VALECHA N., BISWAS S. 1993: In vitro activity of fluoroquinolones against chloroquine-sensitive and chloroquine-resistant Plasmodium falciparum. Indian J. Malariol. 30: 67-73.

VIVARĖS C.P., GOUY M., THOARAT F., MÉTÉNIER G. 2002: Functional and evolutionary analysis of a eukaryotic parasitic genome. Curr. Opin. Microbiol. 5: 499505.

VOSSBRINCK C.R., ANDREADIS T.G., WEISS L.M. 2004: Phylogenetics: taxonomy and the microsporidia as derived

Received 5 October 2004 fungi. In: D.S. Lindsay and L.M. Weiss (Eds.), Opportunistic Infections: Toxoplasma, Sarcocystis, and Microsporidia. Kluwer Academic Publishers, Boston, pp. 189213.

VOSSBRINCK C.R., MADDOX J.V., FRIEDMAN S.S., DEBRUNNER-VOSSBRINCK B.A., WOESE C.R. 1987: Ribosomal RNA sequence suggests microsporidia are extremely ancient eukaryotes. Nature 326: 411-414.

WATT G., SHANKS G.D., EDSTEIN M.D., PAVANAND K., WEBSTER H.K., WECHGRITAYA S. 1991: Ciprofloxacin treatment of drug-resistant falciparum malaria. J. Infect. Dis. 164: 602-604.

WEBER R., DEPLAZES P., SCHWARTZ D. 2000: Diagnosis and clinical aspects of human microsporidiosis. Contrib. Microbiol. 6: 166-192.

WEISS L.M., EDLIND T.D., VOSSBRINCK C.R., HASHIMOTO T. 1999: Microsporidian molecular phylogeny: the fungal connection. J. Eukaryot. Microbiol. 46: 17S-18S.

Accepted 5 January 2005 